\title{
Whole genome sequencing and phylogenetic analysis of West Nile virus lineage 1 and lineage 2 from human cases of infection, Italy, August 2013
}

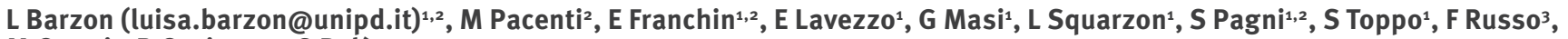 \\ M Cattai ${ }^{2}$, R Cusinato ${ }^{2}$, G Palù ${ }^{1,2}$ \\ 1. Department of Molecular Medicine, University of Padova, Padova, Italy \\ 2. Regional Reference Laboratory, Microbiology and Virology Unit, Padova University Hospital, Padova, Italy \\ 3. Department of Public Health and Screening, Veneto Region, Venice, Italy
}

Citation style for this article:

Barzon L, Pacenti M, Franchin E, Lavezzo E, Masi G, Squarzon L, Pagni S, Toppo S, Russo F, Cattai M, Cusinato R, Palù G. Whole genome sequencing and phylogenetic analysis of West Nile virus lineage 1 and lineage 2 from human cases of infection, Italy, August 2013. Euro Surveill. 2013;18(38):pii=20591. Available online: http://www.eurosurveillance.org/ViewArticle.aspx?Articleld=20591

Article submitted on 31 August 2013 / published on 19 September 2013

A human outbreak of West Nile virus (WNV) infection caused by WNV lineage 2 is ongoing in northern Italy. Analysis of six WNV genome sequences obtained from clinical specimens demonstrated similarities with strains circulating in central Europe and Greece and the presence of unique amino acid changes that identify a new viral strain. In addition, WNV lineage 1 Livenza, responsible for a large outbreak in north-eastern Italy in 2012, was fully sequenced from a blood donor during this 2013 outbreak.

A human outbreak of West Nile virus (WNV) infection is ongoing in northern Italy. We report here the clinical presentation, laboratory test results, and WNV full genome sequences from human cases of WNV infection which were diagnosed in August 2013 in the Veneto region. This region is one of the most affected by the outbreak. WNV genome sequences obtained from clinical specimens of infected individuals were subjected to phylogenetic analysis, in order to gain information on the origin and evolutionary history of the responsible viral strains.

\section{Cases of West Nile virus infection}

\section{from the Veneto region}

Cases included five patients with laboratory-confirmed West Nile neuroinvasive disease (WNND) and four with West Nile fever (WNF), aged 51 to 88 years-old, who were resident in Rovigo, Padova, and Verona provinces (Figure 1). In addition, three WNV RNA-positive blood and organ donors were identified by screening in Padova, Verona, and Venice provinces and, besides the 12 confirmed cases, further possible cases are currently under investigation. Confirmed human cases of WNND have also been notified in regions neighbouring Veneto, namely Emilia Romagna and Lombardy [1].

Of the 12 confirmed cases reported in Veneto, WNV lineage 2 (lin2) RNA was identified in plasma and/or urine of seven patients with WNND or WNF, and in a blood donor, while WNV lin1 was respectively detected in an organ donor and in a blood donor. The sites where different WNV lineages were identified are indicated in Figure 1.

\section{Clinical and laboratory findings}

A summary of clinical and laboratory findings from confirmed cases is reported in Table 1 . Clinical presentation of patients with WNND and WNF included arthralgia, fatigue, fever $\left(\geq 38^{\circ} \mathrm{C}\right)$, headache, myalgia, while patients with WNND had neurological manifestations, such as encephalitis, meningitis and paralysis. Mild symptoms (i.e. arthralgia, headache, myalgia, but not fever) occurred also in a WNV-positive blood donor a few days before donation. No deaths due to WNV infection were reported.

Isolation of the virus in cell cultures was obtained from urine samples collected from three patients with WNND or WNF and from two blood donors. Laboratory methods were performed as previously described [2].

\section{Epidemiological situation of West Nile virus infection in Europe and Italy}

Since 2010, WNV, a mosquito-borne flavivirus, has become a public health concern in Europe, as it has been responsible for an increasing number of epidemic outbreaks in European countries and in neighbouring countries in the Mediterranean basin as well as in the Russian Federation [3]. In fact, after large human outbreaks with hundreds of cases of neuroinvasive disease (WNND) occurred in Romania in 1996 and in Russia in 1999, only small outbreaks were reported in European and Mediterranean countries, generally caused by WNV lin1 strains [4]. The epidemiological situation in Europe changed in 2010, when two large human outbreaks occurred in Greece [5] and in the Volgograd region, Russia $[6,7]$. During these two outbreaks, two 
Map showing the places of residence of human cases of West Nile virus (WNV) infection confirmed in the Veneto region, Italy, August $2013(\mathrm{n}=12)$

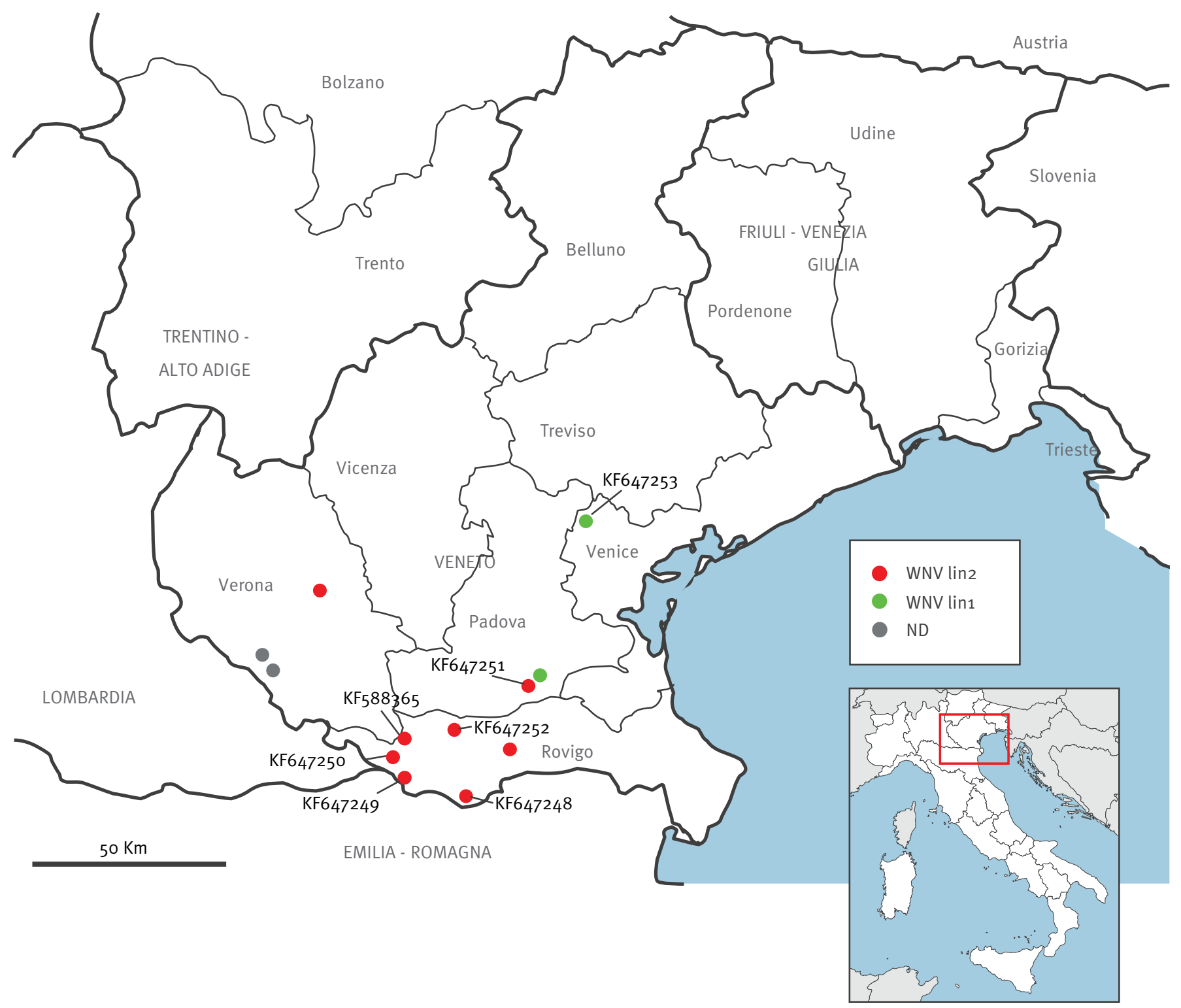

ND: WNV case whereby WNV lineage was not determined; WNV lin1: WNV case with WNV lineage 1 infection; WNV lin2: WNV case with WNV lineage 2 infection.

GenBank accession numbers of WNV genome sequences are indicated near the corresponding case symbols.

unrelated WNV lin2 genotypes were respectively characterised. The genotype in the Greek outbreak (GreeceNea Santa-2010) [8] was similar to that first found in a goshawk in Hungary in 2004 (Hungaryo4 strain) [9] while in the Volgograd outbreak the genotype was similar to that prior detected in human brain and blood samples in 2007 in Volgograd [6]. Recent epidemiological data indicate that WNV lin2 of the Greek/Hungarian cluster is spreading to other central and southern European countries $[10,11]$, such as Serbia, where a large human outbreak occurred in 2012 [7] and is ongoing in 2013 [1].
The outbreak described in this report represents the first human outbreak of WNV linz infection reported in Italy. In fact, in Italy, most cases of human infection reported before 2013 were caused by WNV lin1. In particular, two unrelated WNV lin1 strains, both classified within the Mediterranean cluster by phylogenetic analysis, had been responsible for two different outbreaks in northern Italy. The first outbreak between 2008 and 2009 was caused by the WNV lin1 Italy 2008-2009 strain [12-14] and occurred in the same areas that are currently affected by WNV lin2 circulation, namely those surrounding the Po river in the Veneto, EmiliaRomagna, and Lombardy regions $[12,15]$; the second 


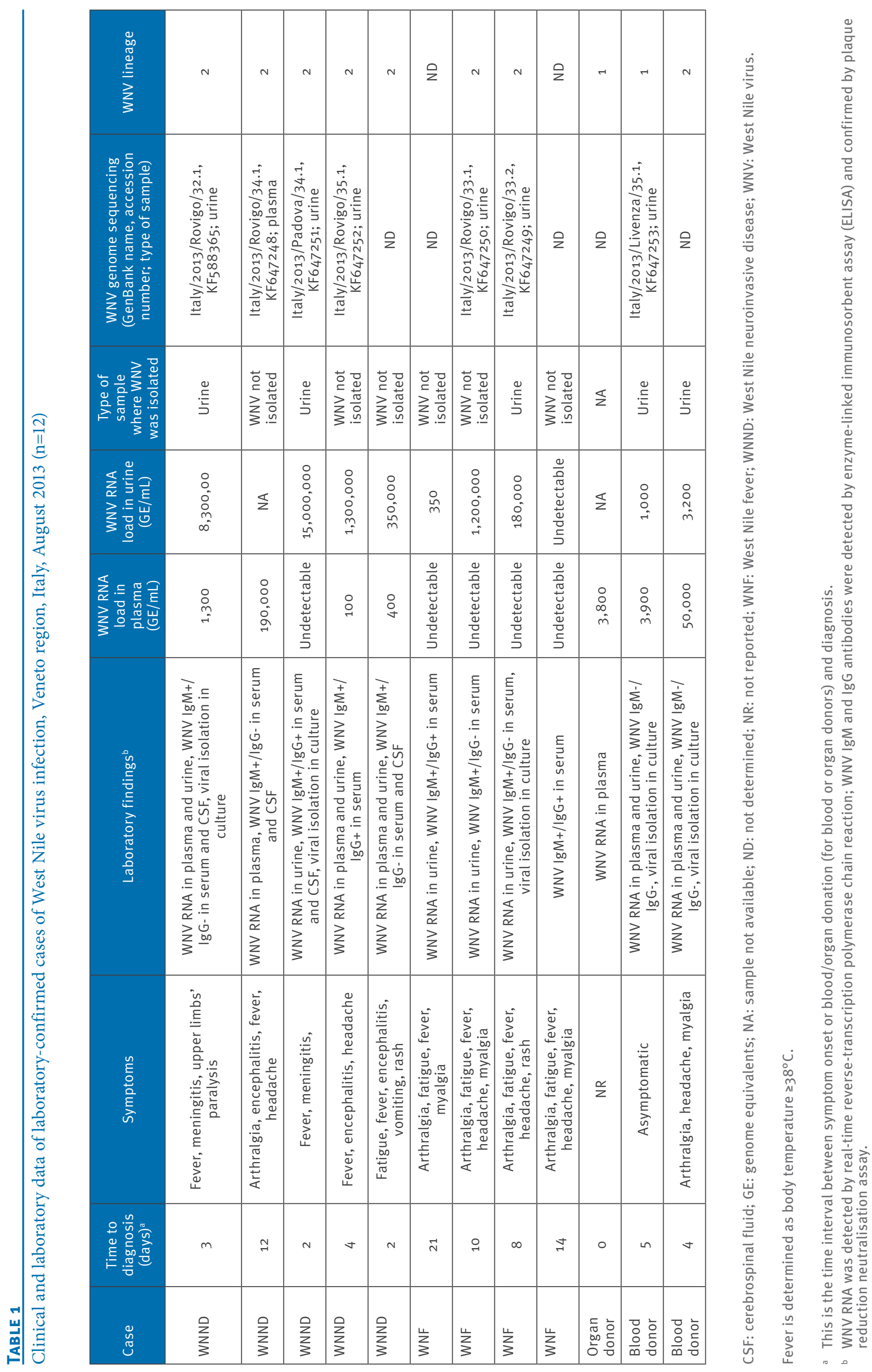


Molecular phylogenetic analysis of six West Nile virus lineage 2 genome sequences detected in individuals from the Veneto region, Italy, August 2013

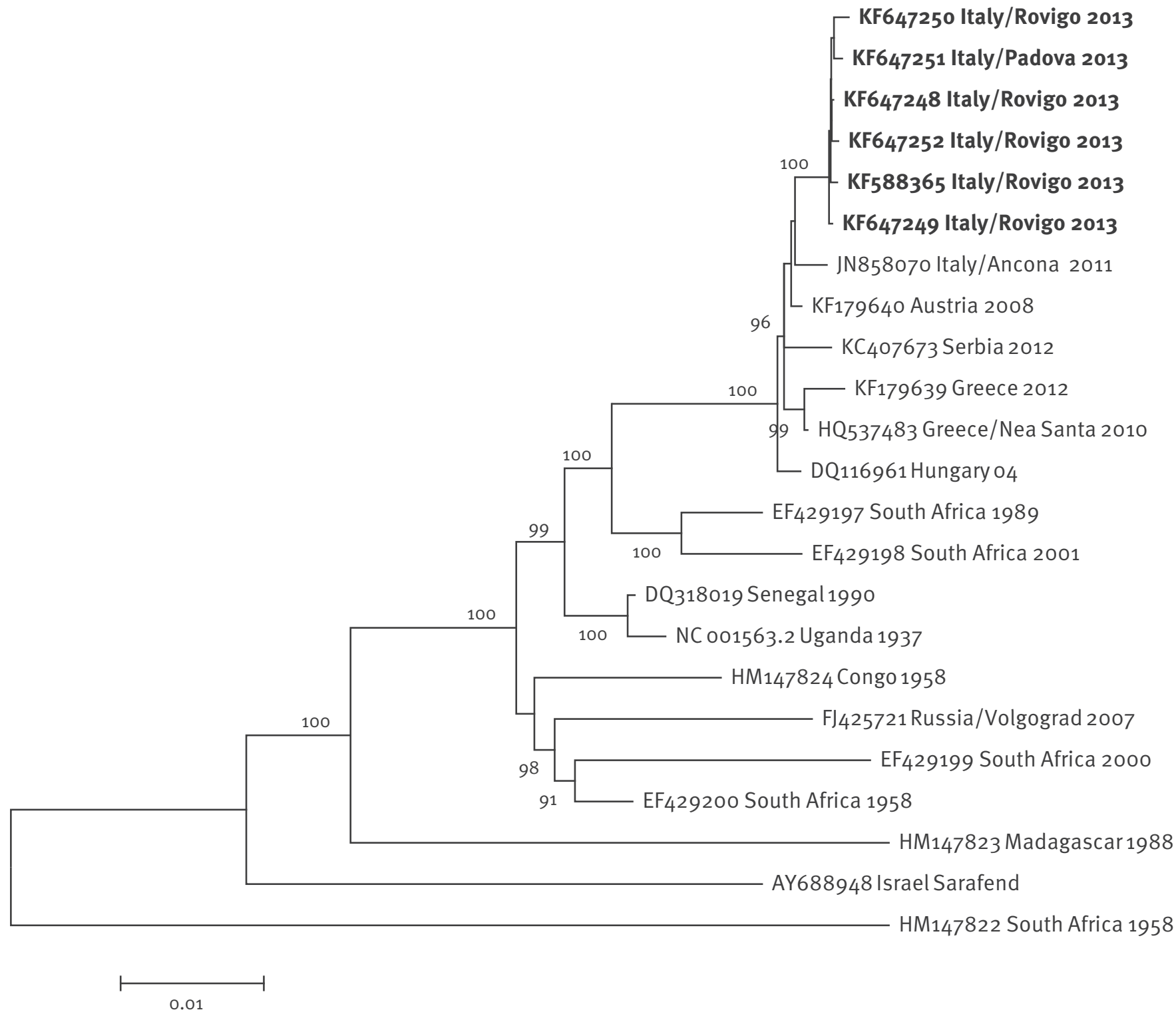

Sequences detected in individuals from the Veneto region are shown in bold font. The evolutionary history was inferred by using the Maximum Likelihood method based on the Kimura 2-parameter model [25]. The bootstrap consensus tree inferred from 1,000 replicates [26] is taken to represent the evolutionary history of the taxa analysed [26]. Branches corresponding to partitions reproduced in less than $50 \%$ bootstrap replicates are collapsed. The percentage of replicate trees in which the associated taxa clustered together in the bootstrap test $(1,000$ replicates) is shown next to the branches (values $\geq 80$ ) [26]. The tree is drawn to scale, with branch lengths measured in the number of substitutions per site. The analysis involved 23 nucleotide sequences. All positions containing gaps and missing data were eliminated. There were a total of 8,586 positions in the final dataset. Evolutionary analyses were conducted in MEGA5 [27].

outbreak took place between 2011 and 2012 in the Venice and Treviso provinces of the Veneto region and was caused by the WNV lin1 Livenza strain $[16,17]$.

Before 2013 only two unrelated human cases of WNV lin2 infection representing the Greek/Hungarian cluster were documented in the country. These had occurred in 2011 and included one case in Ancona (Marche region) and one in Olbia (Sardinia region), respectively $[18,19]$. In 2011 and 2012, however, WNV linz belonging to the
Greek/Hungarian cluster was detected by entomological and veterinary surveillance in the island of Sardinia as well as in the Veneto and Friuli-Venezia Giulia regions in north-eastern Italy in areas where WNV lin1 was also circulating [20-22].

The fact that most human cases from Veneto in August 2013 are affected by WNV lin2 could suggest that this lineage has now become more widespread in northeastern Italy and that it is playing an important part in 


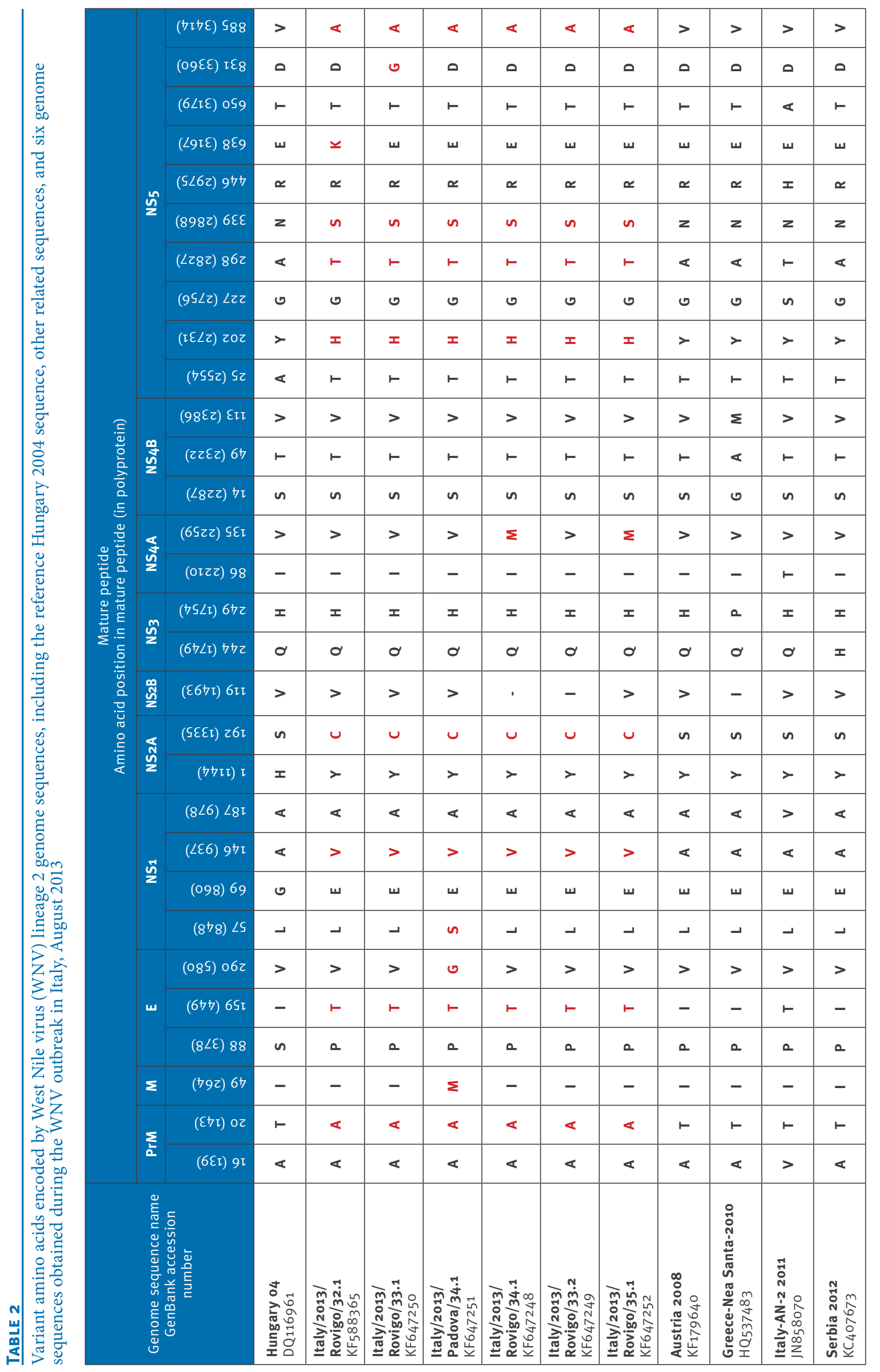




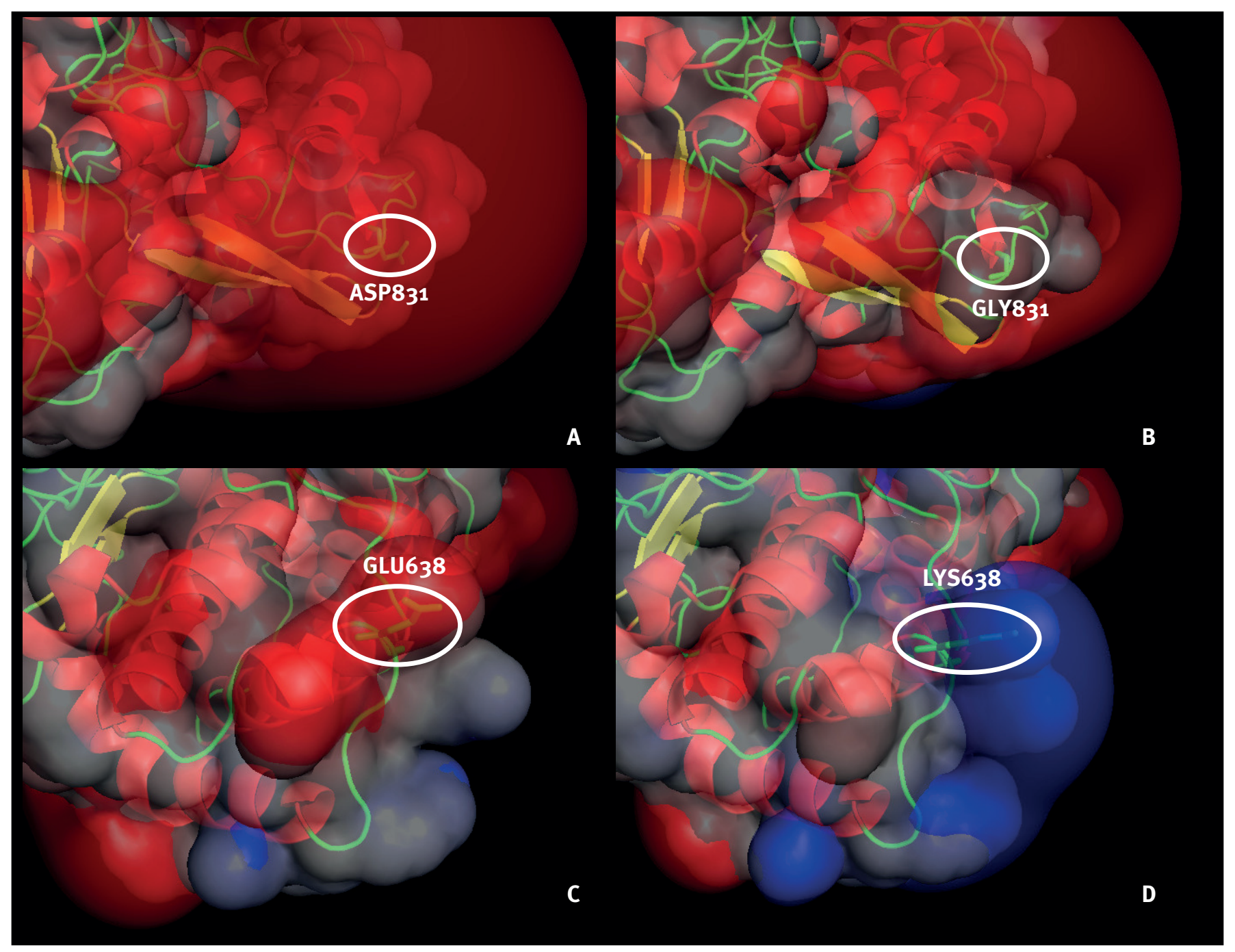

Panels A and B show a mutation from ASP831 to GLY831 and panels C and D show a mutation from GLU638 to LYS638.

The $3 \mathrm{D}$ images are predicted by in silico site-directed mutagenesis based on the Protein Data Bank (PDB) $2 \mathrm{HCN}$ template [28] Best rotamer of side chain of LYS638 has been placed in place of corresponding GLU638 in 2HCN template. GLY831 has been obtained by removing the side chain of corresponding ASP831 in $2 \mathrm{HCN}$ template. Structures rendering has been obtained by Pymol 1.5.0.3 (http://www.pymol.org). Per-atom charge and radius have been calculated by CHARMM force field using pdb2pqr tool (http://www.poissonboltzmann.org/pdb2pqr [29,30]). Molecular surface is coloured according to the potential on solvent accessible surface and has been calculated using APBS tool (http://www. poissonboltzmann.org/apbs [31]) for Poisson-Boltzmann electrostatics and shown in the range of $-5 /+5 \mathrm{kT} / \mathrm{e}$.

Negative isosurface and positive isosurface are shown with a gradient that goes from red (-2 kT/e) to blue (+2 kT/e) respectively.

GLY831 weakens the negative surface (see panel B compared with panel A) whereas LYS638 contributes to change the sign of the surface charge from negative to positive (see panel C compared with panel D).

the current human outbreak. To gain more insight into the origin of the WNV lin2 and WNV lin1 involved in this ongoing outbreak, respective genome sequences were sought.

Genome sequences derived from the 2013 West Nile virus outbreak cases in Veneto A total of seven WNV lin2 and one WNV lin1 genome sequences were derived from blood or urine samples of cases, including two full genome sequences of WNV lin2 sequenced from samples collected at three daysinterval from the same patient. Six WNV complete genome sequences and one almost complete were submitted to GenBank with accession numbers KF588365 and KF647248-KF647253.

Analysis of the West Nile virus lineage 1 sequence Sequencing of the full genome of WNV lin1 detected in a blood donor from Venice province (i.e. Italy/2013/ Livenza/35.1, GenBank accession number: KF647253) 
demonstrated over $99.9 \%$ nucleotide sequence identity with the Livenza strains fully sequenced in 2011 and 2012 and responsible for the large human outbreak that occurred in Venice and Treviso provinces in 2012 $[16,17]$. This finding demonstrates that the Livenza strain is still circulating in the affected area.

Phylogenetic and amino acid analyses of West Nile virus lineage 2 sequences

Sequence alignment demonstrated that all the genome sequences derived from the cases infected with WNV lin2 (WNV lin2 Italy/2013) shared over $99.9 \%$ nucleotide sequence identity, and the two WNV linz genome sequences derived from the same patient had 100\% identity. At variance, the identity with other WNV lin2 genomes was lower, e.g. $99.5 \%$ vs the WNV lin2 Hungaryo 4 strain [9] and $99.4 \%$ vs a WNV lin2 GreeceNea Santa-2010 strain [8]. Likewise $99.7 \%$ and $99.1 \%$ nucleotide sequence identities were also respectively observed with the NS3 and NS 5 regions of a WNV lin2 detected in a mosquito pool collected in 2012 in Rovigo province, in the same area of the current outbreak [21]. Finally the present outbreak sequences presented 99.5 $\%$ nucleotide sequence identity with the full genome of the WNV linz isolated from the patient in Ancona in 2011 [19]. Phylogenetic analysis showed that the WNV lin2 Italy/2013 genomes were included in the Greek/Hungarian cluster which contains the Hungarian (Hungaryo4) and Greek (Greece-Nea Santa-2010) strains, but generated a distinct branch in the phylogenetic tree, indicating that they represent a new strain (Figure 2). This finding suggests that a single monophyletic group of WNV lin2 is arising from the Greek/ Hungarian cluster, which corresponds to a group of viruses that are evolving as they reach new territories in their spread from central Europe and areas in the Balkans.

At protein level, the WNV lin2 Italy/2013 genomes encoded a set of unique amino acids compared to other fully sequenced WNV lin2 genomes of the Greek/ Hungarian cluster (Table 2). Most of the substitutions compared to the Hungary 04 reference apparently seem not to change dramatically the properties of referring proteins. Nonetheless, mutations observed on the surface of the non-structural protein 5 (NS5) protein (i.e. $\mathrm{E} 638 \mathrm{~K}^{\star}$ and $\mathrm{D} 831 \mathrm{G}$ ) in two individual genome sequences were predicted by in silico site-directed mutagenesis to cause a local altered electrostatic potential in the RNAdirected RNA polymerase domain (Figure 3). The relevance of these mutations will be assessed by further sequencing of WNV genome sequences and by experimental studies with viral isolates and site-directed mutagenesis of infectious clones. Of note, none of the WNV lin2 Italy/2013 genomes had the $\mathrm{H}_{249} \mathrm{P}$ substitution in non-structural protein $3\left(\mathrm{NS}_{3}\right)$ that characterises the Greece-Nea Santa-2010 strain.

\section{Conclusion}

Overall, the results of this molecular epidemiology study shows that genetically different lineages of WNV are capable of establishing in Europe, remain circulating for several years in the same territory, and spread slowly to neighbouring areas, in agreement with other reports from Europe $[13,23]$. In this local transmission and spread dynamics in Europe, WNV overwintering in mosquitoes and amplification in local susceptible bird populations are key factors, while WNV re-introduction by migrating birds from long-distance Euro-African routes seems to be less relevant [24].

In conclusion, a novel WNV lin2 strain of the Greek/ Hungarian cluster is responsible for a human outbreak of neuroinvasive disease that is ongoing in northern Italy. The virus is co-circulating with the WNV lin1 Livenza strain that caused a large human outbreak in 2012.

*Authors' correction:

At the request of the authors, 'E636K' was replaced with 'E638K'. This change was made on 27 September 2013.

Acknowledgements

This study was supported by Veneto region and by the European Commission under FP7, Project 261426 (WINGSWest Nile Integrated Shield Project).

Conflict of interest

None declared.

Authors' contributions

Luisa Barzon coordinated the study and wrote the manuscript; Monia Pacenti, Riccardo Cusinato, Silvana Pagni, Margerita Cattai, and Laura Squarzon performed surveillance activities and virological tests; Elisa Franchin and Giulia Masi performed WNV genome sequencing; Enrico Lavezzo and Stefano Toppo performed bioinformatics analyses of WNV genome sequences; Francesca Russo coordinated WNV surveillance activities; Giorgio Palù supervised the study and revised the manuscript. 


\section{References}

1. European Centre for Disease Prevention and Control (ECDC). West Nile fever maps - situation update 29/08/2013. Stockholm: ECDC. [Accessed 31 Aug 2013]. Available from http://www.ecdc.europa.eu/en/healthtopics/west_nile_fever/ west-nile-fever-maps/pages/index.aspx

2. Barzon L, Pacenti M, Franchin E, Pagni S, Martello T, Cattai $M$, et al. Excretion of West Nile Virus in Urine During Acute Infection. J Infect Dis. 2013; 208(7):1086-92. http://dx.doi.org/10.1093/infdis/jit290 PMid:23821721

3. Sambri V, Capobianchi M, Charrel R, Fyodorova M, Gaibani $P$, Gould E, et al. West Nile virus in Europe: emergence, epidemiology, diagnosis, treatment, and prevention. Clin Microbiol Infect. 2013;19(8): 699-704. http://dx.doi.org/10.1111/1469-0691.12211 PMid:23594175

4. Zeller HG, Schuffenecker I. West Nile virus: an overview of its spread in Europe and the Mediterranean basin in contrast to its spread in the Americas. Eur J Clin Microbiol Infect Dis. 2004;23(3):147-56.

http://dx.doi.org/10.1007/s10096-003-1085-1 PMid:14986160

5. Danis K, Papa A, Theocharopoulos G, Dougas G, Athanasiou M, Detsis $M$, et al. Outbreak of West Nile virus infection in Greece, 2010. Emerg Infect Dis, 2011;17(10):1868-72. http://dx.doi.org/10.3201/eid1710.110525 PMid:22000357 PMCid:PMC3310677

6. Platonov AE, Fedorova MV, Karan LS, Shopenskaya TA, Platonova OV, Zhuravlev VI. Epidemiology of West Nile infection in Volgograd, Russia, in relation to climate change and mosquito (Diptera: Culicidae) bionomics. Parasitol Res. 2008;103 Suppl 1:S45-53.

http://dx.doi.org/10.1007/s00436-008-1050-0 PMid:19030885

7. European Centre for Disease Prevention and Control (ECDC). West Nile fever maps - Historical data (2010 - 2012). Stockholm: ECDC. [Accessed 31 Aug 2013]. Available from: http://www.ecdc.europa.eu/en/healthtopics/west_nile_fever/ west-nile-fever-maps/pages/historical-data.aspx

8. Papa A, Bakonyi T, Xanthopoulou K, Vázquez A, Tenorio A, Nowotny N. Genetic characterization of West Nile virus lineage 2, Greece, 2010. Emerg Infect Dis, 2011;17(5):920-2. http://dx.doi.org/10.3201/eid1705.101759 PMid:21529413 PMCid:PMC3321789

9. Bakonyi T, Ivanics E, Erdélyi K, Ursu K, Ferenczi E, Weissenböck $\mathrm{H}$, Nowotny $\mathrm{N}$. Lineage 1 and 2 strains of encephalitic West Nile virus, central Europe. Emerg Infect Dis. 2006;12(4):618-23. http://dx.doi.org/10.3201/eid1204.051379 PMid:16704810 PMCid:PMC3294705

10. Bakonyi T, Ferenczi E, Erdélyi K, Kutasi O, Csörgő T, Seidel B, et al. Explosive spread of a neuroinvasive lineage 2 West Nile virus in Central Europe, 2008/2009. Vet Microbiol. 2013;165(12):61-70. http://dx.doi.org/10.1016/j.vetmic.2013.03.005 PMid:23570864

11. Ciccozzi M, Peletto S, Cella E, Giovanetti M, Lai A, Gabanelli E, et al. Epidemiological history and phylogeography of West Nile virus lineage 2. Infect Genet Evol. 2013;17:46-50. http://dx.doi.org/10.1016/j.meegid.2013.03.034 PMid:23542457

12. Barzon L, Franchin E, Squarzon L, Lavezzo E, Toppo S, Martello T, et al. Genome sequence analysis of the first human West Nile virus isolated in Italy in 2009. Euro Surveill. 2009;14(44): pii=19384. Available from: http://www. eurosurveillance.org/ViewArticle. aspx?Articleld =19384

13. Sotelo E, Fernández-Pinero J, Llorente F, Vázquez A, Moreno $A$, Agüero M, et al. Phylogenetic relationships of Western Mediterranean West Nile virus strains (1996-2010) using fulllength genome sequences: single or multiple introductions? J Gen Virol. 2011;92(Pt 11):2512-22. http://dx.doi.org/10.1099/vir.0.033829-0 PMid:21775579

14. Rossini G, Carletti F, Bordi L, Cavrini F, Gaibani P, Landini MP, et al. Phylogenetic analysis of West Nile virus isolates, Italy, 2008-2009. Emerg Infect Dis. 2011;17(5):903-6. http://dx.doi.org/10.3201/eid1705.101569 PMid:21529408 PMCid:PMC3321781

15. Angelini P, Tamba M, Finarelli AC, Bellini R, Albieri A, Bonilauri $P$, et al. West Nile virus circulation in EmiliaRomagna, Italy: the integrated surveillance system 2009. Euro Surveill. 2010;15(16): pii=19547. Available from: http://www. eurosurveillance.org/ViewArticle.aspx?Articleld=19547 PMid:20430000

16. Barzon L, Pacenti M, Franchin E, Squarzon L, Lavezzo E, Toppo S, et al. Novel West Nile virus lineage 1a full genome sequences from human cases of infection in north-eastern Italy, 2011. Clin Microbiol Infect. 2012;18(12):E541-4. PMid:23004685

17. Barzon L, Pacenti M, Franchin E, Martello T, Lavezzo E, Squarzon L, et al. Clinical and virological findings in the ongoing outbreak of West Nile virus Livenza strain in northern Italy, July to September 2012. Euro Surveill. 2012;17(36): $\mathrm{pii}=20260$. Available from: http://www. eurosurveillance.org/ViewArticle.aspx?Articleld=20260

18. Magurano F, Remoli ME, Baggieri M, Fortuna C, Marchi A, Fiorentini $C$, et al. Circulation of West Nile virus lineage 1 and 2 during an outbreak in Italy. Clin Microbiol Infect. 2012;18(12): E545-7. PMid:23020657

19. Bagnarelli P, Marinelli K, Trotta D, Monachetti A, Tavio M, Del Gobbo R, et al. Human case of autochthonous West Nile virus lineage 2 infection in Italy, September 2011. Euro Surveill. 2011;16(43):pii=20002. Available from: http://www. eurosurveillance.org/ViewArticle.aspx?Articleld=20002 PMid:22085600

20. Savini G, Capelli G, Monaco F, Polci A, Russo F, Di Gennaro $A$, et al. Evidence of West Nile virus lineage 2 circulation in Northern Italy. Vet Microbiol. 2012;158(3-4):267-73. http://dx.doi.org/10.1016/j.vetmic.2012.02.018 PMid:22406344

21. Capelli G, Ravagnan S, Montarsi F, Ciocchetta S, Cazzin S, Bonfanti L, et al. Further evidence of lineage 2 West Nile Virus in Culex pipiens of North-Eastern Italy. Vet Ital. 2013 Sep 4.

22. Savini G, Puggioni G, DI Gennaro A, DI Francesco G, Rocchigiani AM, Polci A, et al. West Nile virus lineage 2 in Sardinian wild birds in 2012: a further threat to public health. Epidemiol Infect. 2013 Jan 24:1-4. http://dx.doi.org/10.1017/S0950268812003147 PMid:23343580

23. Bakonyi T, Ferenczi E, Erdélyi K, Kutasi O, Csörgő T, Seidel B, et al. Explosive spread of a neuroinvasive lineage 2 West Nile virus in Central Europe, 2008/2009. Vet Microbiol. 2013;165(1 2):61-70.

http://dx.doi.org/10.1016/j.vetmic.2013.03.005 PMid:23570864

24. Calistri P, Giovannini A, Hubalek Z, Ionescu A, Monaco F, Savini G, et al. Epidemiology of west nile in europe and in the mediterranean basin. Open Virol J. 2010;4:29-37. PMid:20517490 PMCid:PMC2878979

25. Kimura M. A simple method for estimating evolutionary rate of base substitutions through comparative studies of nucleotide sequences. J Mol Evol. 1980;16(2):111-20. http://dx.doi.org/10.1007/BF01731581 PMid:7463489

26. Felsenstein J. Confidence limits on phylogenies: An approach using the bootstrap. Evolution. 1985:39(4):783-91. http://dx.doi.org/10.2307/2408678

27. Tamura K, Peterson D, Peterson N, Stecher G, Nei M, Kumar S. MEGA5: molecular evolutionary genetics analysis using maximum likelihood, evolutionary distance, and maximum parsimony methods. Mol Biol Evol. 2011;28(10):2731-9. http://dx.doi.org/10.1093/molbev/msr121 PMid:21546353 PMCid:PMC3203626

28. Malet H, Egloff MP, Selisko B, Butcher RE, Wright PJ, Roberts $M$, et al. Crystal structure of the RNA polymerase domain of the West Nile virus non-structural protein 5. J Biol Chem. 2007;282(14):10678-89. http://dx.doi.org/10.1074/jbc.M607273200 PMid:17287213

29. Dolinsky TJ, Czodrowski P, Li H, Nielsen JE, Jensen JH, Klebe $\mathrm{G}$, et al. PDB2PQR: Expanding and upgrading automated preparation of biomolecular structures for molecular simulations. Nucleic Acids Res. 2007;35(Web Server issue):W522-5.

30. Dolinsky TJ, Nielsen JE, McCammon JA, Baker NA. PDB2PQR: an automated pipeline for the setup, execution, and analysis of Poisson-Boltzmann electrostatics calculations. Nucleic Acids Res. 2004;32(Web Server issue):W665-7.

31. Baker NA, Sept D, Joseph S, Holst MJ, McCammon JA. Electrostatics of nanosystems: application to microtubules and the ribosome. Proc Natl Acad Sci U S A. 2001;98(18):10037-41. http://dx.doi.org/10.1073/pnas.181342398 PMid:11517324 PMCid:PMC56910 